\title{
POST-TRAUMATIC AND POST-MODERN: A SOUTH AFRICAN "ELECTRA"
}

\author{
E Steinmeyer (University of KwaZulu-Natal)
}

\begin{abstract}
The ancient myth of Electra seems to be of particular interest to South African writers and playwrights. This article focuses on the adaptation by Mervyn McMurtry, entitled Electra, which was produced in Durban in 2000. The underlying theme of his adaptation, which is based on the four Greek "Electra" tragedies by Aeschylus, Sophocles and Euripides, is the question of truth. This question - an important post-modern one - was of particular relevance for the Truth and Reconciliation Commission (TRC) in South Africa as it tried to deal with the legacy of the former apartheid regime. McMurtry's play begins with a prologue six days after the matricide, while the actual play is performed as a sort of flashback. All the characters suffer from various symptoms of post-traumatic stress disorder. The chorus consists exclusively of women who all have been victims / survivors of male violence. This article proposes that McMurtry uses the ancient Electra myth to reflect on the situation of contemporary South African society (and particularly women), as it struggles to come to terms with a traumatic past.
\end{abstract}

Of the countless tales in Greek and Roman mythology, the story of Electra can probably be considered as the most prominent saga about a family governed by feelings of hatred, anger, revenge, retribution, murder and a lack of understanding or forgiveness. This ancient myth seems to have appealed particularly to modern South African writers and playwrights since the abolition of apartheid in 1994; in my research on adaptations of ancient Greek and Roman drama in African literatures, I have come across five South African plays which re-work the ancient Electra myth, ${ }^{1}$ while to date I have not been able to find any other African adaptation of the Electra myth outside South Africa. ${ }^{2}$

In this article I would like to focus on Mervyn McMurtry's play Electra, which was performed in 2000 at the University of KwaZulu-Natal (University of Natal at the time). The core of McMurtry's version consists of a new adaptation of Sophocles' Electra, enriched with elements from Aeschylus and Euripides. The actual play is preceded by a prologue, which describes the situation six days after the killings have taken place — as in the prologue of Euripides' Orestes. McMurtry's play itself is presented as a sort of flashback. In the following discussion I shall focus on certain key aspects of McMurtry's post-modern approach to the Electra story, with its emphasis on post-traumatic stress disorder in relation to the Truth and Reconciliation Commission (TRC), which was established in 1995.

1 Tug Yourgrau 1993: The Song of Jacob Zulu (re-working the Oresteia); Mark Fleishman et al. 1998: In the City of Paradise; Mervyn McMurtry et al 2000: Electra; Yael Farber 2003: Molora; Mervyn McMurtry, Tamar Meskin \& Lliane Loots 2007: Family.

2 In my opinion the above mentioned issues were more prominent in South Africa than in other African countries, especially in the aftermath of the apartheid regime and the establishment of the $\mathrm{TRC}$, and therefore, the myth of Electra provided the perfect vehicle to engage with them. 
McMurtry $^{3}$ uses certain theatre devices which seem to be typical of South African theatre practice. He workshopped the text together with his students and he has a multi-racial or non-traditional cast. ${ }^{4} \mathrm{He}$ uses the main ancient sources, i.e. Aeschylus' Choephoroi (Libation Bearers), Sophocles' and Euripides' Electra plays and Euripides' Orestes, but adds a few elements from Euripides' Hecabe and Andromache in the chorus scenes. The main part of his plot follows Sophocles' play very closely, but McMurtry combines the endings of the three ancient plays into one: after the revenge has been carried out Orestes and Electra are suddenly overcome by remorse for killing their mother (Euripides), ${ }^{5}$ and finally Orestes starts to see the Erinyes / Furies and storms off stage (Aeschylus). ${ }^{6}$ McMurtry also adds a confrontation between Electra and Aegisthus: Before Aegisthus is led into the palace, Electra for the first time dares to confront him and to tell him to his face what she always thought of him; she settles her score verbally with him. McMurtry must here have been inspired by Euripides' play, where Electra delivers a persiflage of a funeral speech before Aegisthus' corpse. ${ }^{7}$ The play concludes in a sort of Platonic aporia: the last words of the play - spoken by different members of the chorus in different languages such as Xhosa, Afrikaans, English, and Greek - are "I do not know" (McMurtry 2000:40).

The characters in the play are Electra, Chrysothemis, Clytemnestra, Orestes, Pylades, Aegisthus, the Chorus, and a fictional modern character, a forensic pathologist, who features only in the prologue. With the exception of the pathologist, these are basically the same characters as in Sophocles' play, with the further change that the old instructor has been replaced by the more important figure of Pylades, who features in Aeschylus, where he has only a few, yet very crucial lines, reminding the hesitant Orestes of Apollo's order to carry out the matricide. ${ }^{8}$ Here McMurtry has slightly streamlined the ancient myth by making Pylades the person to whom Electra once handed over Orestes in order to save him from Clytemnestra's and Aegisthus' rage (McMurtry 2000:30-31), not the old instructor or Strophios as in the ancient sources.

The setting is "an open space" with doors leading into the palace (of Mycenae) in the background. According to the production book (title page)

[t]he setting should be both ancient and contemporary, suggestive of a place where the next cycle of killing could happen; a ritualistic slaughterhouse [...].

The play opens with the following scene indicated in the production book:

3 I would like to express my sincere thanks to Professor Mervyn McMurtry (Drama and Performance Studies, University of KwaZulu-Natal) for his generous help in providing me with a copy of the production book and for making himself available for an interview. Without his willingness to participate I would not have been able to undertake this study.

For a good overview on some characteristics of workshop theatre see Fleishman 1990:89.

Electra, 1177-1232.

Libation Bearers, 1048-1062.

Electra, 907-956.

Libation Bearers, 900-903. 
Electra, wearing her father's greatcoat, seated; Orestes lying on the floor, in a straightjacket; Chrysothemis, clutching at a wreath; Pylades cleaning a weapon with a bloodied cloth; a pathologist holding a report. Centrestage, a trolley with the body of Clytemnestra, covered by a sheet (McMurtry 2000:1).

In addition, there is the chorus, "a group of women huddled like refugees" (1). They are slaves, as the Trojan captives are in Aeschylus, victims of war and politics. Their statements illustrate the wide range of cruelties which women have often suffered from men, the tortures female victims have had - and still have - to endure from male perpetrators. McMurtry had the intriguing idea of introducing a number of testimonies "by victims and witnesses of atrocities, in the present and in the past, in our own country and elsewhere" (title page) into the prologue and the choral odes, replacing the ancient songs partially with these statements. This concept provides his adaptation of the Electra myth with a fascinating new framework: the issues of violence against women and the abuse of women by men, women as victims of patriarchal structures and women as victims of situations beyond their control, which will become one of the main focuses of his play. This also opens up interesting new questions about the power relationships between the female characters and the male characters in the play. The fact that McMurtry does not restrict himself to a specific period or a specific location gives his interpretation a more universal application than others. The problem of male dominance over women is a timeless one; it is as actual today as it was in the mystical past.

\section{Post-traumatic}

Since the prologue represents McMurtry's most original invention and sets up the framework for the actual play to follow, it deserves a close examination. The prologue begins with the report of the forensic pathologist who has examined Clytemnestra's corpse. The autopsy itself and the fatal wounds are described in meticulous anatomical detail, but it is his last sentence that is most revealing: "The cause of death was heart failure" (McMurtry 2000:1). This alludes to the way in which official medical statements are manipulated by forensic experts when a political prisoner dies as a consequence of torture and violence. Here one can probably find the first link to the apartheid regime in South Africa, where this sort of explanation was common. Denis Herbstein gives two cases in which the evidence of torture was explained away by findings of "hanged himself" or "fallen down the stairwell" (2004:87; see also 159). The invention of a forensic pathologist in McMurtry's play also sheds a critical light on the role which some health professionals played under the apartheid regime in South Africa. Modern research has shown that there are always "some health professionals [who] become involved in facilitating torture and political trauma" (Simpson 1995:188) in support of a totalitarian political regime. Simpson provides a list of ways in which these individuals have assisted in the abuse of human rights and especially in torture (204-205): 
There are many ways in which they [the health professionals] can hide evidence of torture: by keeping no medical records; by omitting or falsifying relevant details in such records; by giving cynical or false evidence in court or at inquests or inquiries, denying the facts; by misrepresenting scientific knowledge in interpreting such evidence in favour of the official denials of abuse; or by explaining away the facts so as to enable or encourage the court to ignore evidence strongly suggestive of torture (205).

Simpson goes on to give the example of a "forensic specialist working with the [South African] security police, who specialised solely in preparing court reports, and who has not been known to agree that any black political prisoner has ever suffered from any serious clinical state" (206). In the case of McMurtry's production, crucial questions arise: which and whose purpose does the report of the forensic pathologist serve? Cui bono? By whom was the report requested? By "the people" who are going to try Orestes and Electra for murder in order to provide some evidence to the jury? Will the formulation "the fatal wound to the neck ... inflicted with considerable force" (McMurtry, 2000:1) suffice for a charge of murder? Or will it be invalidated by the concluding result that "[t]he cause of death was heart failure" (1)? What has the fact that "the subject was in good general health" and did not show any gynaecological abnormalities to do with the cause of death? Why is the fact that Clytemnestra was stabbed several times before the final blow minimised by the formulation "lacerations" (1)? It seems that the report serves to illustrate McMurtry's underlying theme of the questionability of truth which will be discussed later. The facts presented seem to be accurate - even the heart failure is plausible after a great loss of blood so that each party can arrive at their own version of what "really" happened.

The opening report of the forensic pathologist facilitates an approach to the other characters in the play also in terms of pathology-psychopathology. After he has left the stage, the audience is faced with the other characters as described earlier. All of them appear to suffer from different sub-types of anxiety disorder as a result of having been exposed to an extremely upsetting situation, i.e. the murder of Clytemnestra and Aegisthus. "[S]eeing another person who has been, is being (or has recently been), seriously injured or killed as the result of an accident or physical violence" is listed by Peterson, Prout and Schwarz among the Diagnostic Criteria for Post-Traumatic Stress Disorder (1991:13). According to Lourens Schlebusch, "anxiety and depression are two of the most common responses to inordinate stress levels" (2000:42). The symptoms of anxiety (and depression) manifest themselves in a trifold reaction — physical, psychological, and behavioural - which in psychology is called the "biopsychosocial approach" (35). Several of these symptoms can be observed in the characters on stage. Pylades seems to suffer from an "obsessive compulsive disorder (OCD) [...] which consists of repetitive, intentional or stereotyped thoughts or acts" (45); he is incessantly cleaning the murder weapon with an already bloodied cloth, as if he were under an irresistible impulse.

Chrysothemis also displays this same syndrome of abnormal behaviour: the neurotic and exaggerated desire to clean. This also forms part of the group of Anxiety Disorders as a psychological sign of unresolved problems and is similarly listed under "obsessive compulsive disorder". This OCD can be observed in a person having a 
feeling of not getting enough affection, but also in victims of abuse, for example in children who have been sexually abused, or in someone who has a strong feeling of guilt, which is the case here. Chrysothemis describes in an exhausting and repetitive manner how she cleanses and cares for her skin, the products she uses, the other means she applies in order to relax herself (such as meditation) and to purify her system, and how she seeks relief from the memories by having a facial and getting her hair done (McMurtry 2000:4, 6). Many types of skin disorders are frequent physical reactions to excessive stress (Schlebusch 2000:38-39) and can result in even more stress for the person who tries to restore a healthy-looking skin. ${ }^{9}$ Chrysothemis displays other stress reactions known as "defence mechanisms", which Schlebusch defines in the following way: "Defence-oriented reactions [...] are directed primarily at protecting yourself from being psychologically damaged by stress" (2000:67). Several of the so-called "common defence mechanisms" can be found in Chrysothemis, such as denial, repression, suppression and sublimation. The first three are revealed by her words "No, I don't know anything. I don't remember" (McMurtry 2000:4), - repression being defined by Schlebusch as "preventing [the] thoughts from getting into conscious awareness" (2000:68) and suppression as "postponement of threatening feelings from entering [the] conscious awareness" (68). Sublimation, "redirecting [the] feelings into some other worthwhile activity" (68) can be seen in Chrysothemis' statement: "I try to say nice things to myself, about [m]yself, take better care of myself. I'll have a facial, get my hair done [...]" (McMurtry 2000:6).

Next in the prologue, Orestes, dressed in a straightjacket, is suffering from hallucinations and feels persecuted and tortured by the Erinyes, who, as Electra points out, exist only in his imagination (5). His phases of hallucination and violent outburst are interspersed with phases of deep sleep. These three symptoms, "derealisation, losing control and disturbed sleeping pattern" (Schlebusch 2000:44), are again typical symptoms of anxiety. The medical description sheds further light on Orestes' condition in Euripides' Orestes. In both versions, Orestes is depicted as a madman who has lost control over his mind and is torn apart between sudden panic attacks and moments of absolute exhaustion. Schlebusch defines a panic attack as "a discreet period of sudden intense apprehension, fear discomfort or terror associated with feelings of impending doom, an urge to escape and various other symptoms. They can include the fear of going crazy or losing control [...]. The person has a feeling that a catastrophe is about to happen" (45-46). This fits the depiction of Orestes in McMurtry's prologue very well. He cannot come to terms with the fact that he killed his mother; he is persecuted by the image of the shed blood; the guilt rests on his conscience and allows him no peace. According to Scotti et al., "active participation

$9 \quad$ Antjie Krog also reports these psychosomatic reactions as a result of herself being exposed over a long time to the hearings of the TRC in her capacity as reporter; she says several times that she has, among other symptoms, rashes $(2003: 49$; 97; 168). She was the SABC (South African Broadcasting Corporation) reporter for the TRC hearings and relates her experiences of this time in her book Country of my Skull, which consists of a mixture of original recordings of testimonies from the TRC hearings, background information from the media side and personal reflections and memories about her family and life. She conveys a very good impression of what the members of the TRC, the victims and applicants, and the media representatives went through during the years while the TRC was at work. 
in the [traumatic] event is one factor which can lead to Post-Traumatic Stress Disorder" (1995:189). Orestes also suffers from "acute stress disorder" which manifests in a person "re-experiencing [...] an earlier extremely traumatic experience" in "recurrent and intrusive distressing recollections, images, thoughts, or perceptions of the traumatic event" (Schlebusch 2000:46), and consequently becoming increasingly aroused and also avoiding reminders of the event. Acute stress disorder displays almost identical symptoms to post-traumatic stress disorder, with the difference that the first one "occurs immediately [...] within the first month" (46) after the traumatic event, while the latter develops only after a longer interval. Orestes' anxiety makes also him a victim of (partially self-inflicted) torture.

In the prologue Pylades tries to justify Orestes' actions; he declares the murder a patriotic duty, "a service to his country" (McMurtry 2000:5) and compares Orestes with the men who "went to war" (5). In Pylades' opinion Orestes "should be given amnesty" - a term from the discourse around the TRC in South Africa which screened the applications for amnesty for crimes committed in the context of a political agenda. Whether he will be granted amnesty or not by those people whom Electra calls vaguely "the people" (2) and "they [who] come to fetch us" (6) is left open, because the action of the play ends before Electra and Orestes will be fetched. In Euripides' Orestes, they are the citizens of Argos who want to punish the murderers of their rulers. Here the identity of these "people" remains shadowy. They might be the same people to whom Electra addresses her speech - as indicated in the stage directions - "to a jury or to homicide detectives or to a commission of enquiry" (2); the latter is very likely to be another reference to the TRC.

Electra's entrance in the prologue is introduced by the stage direction referred to above. It says further that she is "speaking as though for the hundredth time" (2), which gives the audience the impression that she is rehearsing her defence speech over and over again, struggling with her argument and desperately trying to present a convincing explanation. Electra tries to be calm and rational, to provide some plausible explanations for what happened. She seems to be the only one on stage who has preserved some sense of reality, while the others speak and act as if in a state of shock. She as well as her sister use some of the "common defence mechanisms" in an attempt at self-protection. But while Chrysothemis tries to avoid the memories of what happened six days earlier, Electra consciously faces the facts and employs "intellectualisation" and "rationalisation" in order to deal with the situation, intellectualisation "using intellectual activity to master [the] feelings" and rationalisation "trying to offer rational explanations to justify [the] attitudes, beliefs or behaviour that might otherwise be unacceptable" (Schlebusch 2000:68). She also experiences what Peterson, Prout and Schwarz call "guilt over responsibility (for inciting the event or failing to prevent it)" (1991:16), when she says that the people are going to try Orestes and herself for murder "[b]ecause: I - encouraged him to do it. I urged him to do it" (McMurtry 2000:2), as Electra did in the Euripidean plays. She repeats this almost word for word at the end of the play, saying to Orestes: "I urged you to do it" (38).

However, Electra does not see herself as a victim, but as a survivor, a term rather used for women who have been subjected to rape or incest and have managed 
to overcome the trauma. Her first words in the prologue are: "There is no suffering, [n]o cruelty, no torture, [t]hat humans cannot live through. Nothing is beyond endurance. We survive" (1, my emphasis). The idea of survival is repeated once again at the beginning of the play, when the chorus tries to calm Electra down with the words: "Others have suffered, Electra. And have had to survive it. We know" (8). On the other hand, Electra is also very afraid of what might happen to her and Orestes. She tries to anticipate what will happen, if "the people" do not believe her and try to force her to speak the "real" truth. This is known in psychology as "anticipatory anxiety" or "excessive worry about what might happen" (Schlebusch 2000:25).

At this moment the women of the chorus enter the action. They all are victims of post-traumatic stress, who have not succeeded in overcoming the memories of the torture and violation they experienced. They paint in great and horrific detail a possible scenario of what might happen to Orestes and Electra, based on their own personal experiences. In these flashbacks or "involuntary occurrences of perceptual disturbances and / or feelings of re-experiencing the event" (43) they re-live once again the traumatic situations they endured. Recent research has shown "that torture is not currently perpetrated for rational reasons (e.g. to elicit information, to punish). Rather, it is more likely that torture is fueled by efforts to destroy the individuality and humanity of the victims" (Vesti \& Kastrup 1995:219). The descriptions of these experiences in the play are neither fictional nor imaginary, but are based on true facts. While creating these testimonies, McMurtry and his cast were inspired by two main sources: the media reports on the atrocities during the war in Bosnia-Herzogovina (very actual at the time of McMurtry's production), and Antjie Krog's book Country of my Skull about which I will give more background later.

The role of the media in reporting disasters and catastrophes is a very complex yet double-edged one, which has been discussed at length by Peter E. Hodgkinson and Michael Stewart (1991:98-103). On the one hand, the media provide an invaluable tool for communicating information about the event in a quick, comprehensive, and accurate way. On the other hand, the interest of the media quickly shifts to new topics, while the actual victims of the traumatic events are in need of a longer coverage. There is also the danger that irresponsible handling of the footage and too much intrusion may further increase the stress level of the victims, and also of (sensitive) viewers and readers. There looms also another potential danger which Schlebusch formulates as "[a]part from the cyber stress and Internet addiction [...], in our modern world with its high technology environment, stress is a common response to information overload" (2000:76). This means that being exposed to too much uncontrolled information creates unhealthy stress for the recipient.

McMurtry makes use of this psychological phenomenon in his production. As the production book states "[b]efore the action starts, the sound of unrest is heard, civil and military, interspersed with media broadcasts" (2000:1), and after the end of the play "the gunfire and unrest heard in the Prologue begin again, until the theatre is filled with the sound" (40). McMurtry mingles the media broadcasts with snippets from commercials, as is usually done in the television news. He deliberately bombards the audience with a flood of kinds of disparate information in quick sequence and extreme noise. Extreme noise is another stress 
factor or stressor (Schlebusch 2000:75), and can also be used as a means of torture (see Vesti \& Kastrup 1995:216). By making his audience feel the symptoms of stress exposure for themselves, McMurtry turns them into further victims of stress disorder in a similar way to the characters on stage.

Of particular interest in this framework are the choral odes, some of which have been replaced by the original testimonies given at the hearings of the TRC and quoted in Antjie Krog's book Country of my Skull. The authenticity of these descriptions allows for moving the chorus from a rather marginal position to being one of the central characters in the play. The fact that all the members of the chorus in McMurtry's play are victims of gruesome atrocities links them together as a group, but because of their individual sufferings each member is an autonomous individual as well. Their "songs" are very closely tied into the text and serve as a transition from one spoken part into the next. There are four of these "songs" in the play. In the first (McMurtry 2000:13-14), which links the two agones between Electra and Chrysothemis and Clytemnestra respectively, the chorus recalls the night in which Troy was destroyed. They contemplate their former life and compare it to their present situation as slaves. The second (22) links the scenes in which Electra has just learned that Orestes is dead and the one in which Chrysothemis arrives joyfully with the news of Orestes' return. The first lines of this "song" are taken from Aeschylus' parodos of the Agamemnon (121, 138, 159), from the narrative of Iphigeneia's sacrifice, followed by three testimonies taken from Krog's book about mothers who have to identify the leftover body parts of their murdered sons. The third one (25-26), linking Chrysothemis' refusal to help Electra and the recognition scene, consists of three parts, of which the second is influenced again by Krog's book about the torture of a woman by members of the police. The last part of the third "song" is an adaptation of the last stanza of the so-called "Hymn to Zeus" in Aeschylus' Agamemnon (176-183) which culminates in the motto that the human being must learn the order of the world through suffering or bad experience. The last "song" takes place between Clytemnestra entering the palace and her cries of death (31-33). It gives examples of how far the feeling of motherhood can be pushed or corrupted; the first two examples are taken again from Krog's book. The passages which I could not trace have been taken probably from media reports about the war in BosniaHerzogovina. The content of the choral testimonies supports or illustrates further what has been said by the characters and gives it a more contemporary interpretation. It applies the narrative of the ancient myth to the world of today, where the same atrocities occur. The testimonies are told exclusively from a female point of view, and in all choral testimonies, women are described as victims of male cruelty, even sadism. Since most often historical events are reported from a male perspective, the choral statements show the other side of the coin: what women have suffered and are able to suffer.

\section{Post-modern}

During his interview with me, McMurtry himself claimed to having used certain post-modern concepts in his interpretation of the Electra myth. Although it is 
impossible to give a comprehensive overview of the complicated and controversial notion of post-modernism, at least some points which might be relevant for a better understanding of McMurtry's production should be discussed. Post-modernism is the name usually given to a cultural movement which emerged in the $60 \mathrm{~s}$ of the $20^{\text {th }}$ century (Foster 1990:xi) as a response to modernism (therefore the much disputed prefix "post") which was certainly also a politically motivated reaction. While the modernist culture is dominated by epistemological questions and "the basic principles of bourgeois liberalism" such as "value, order, meaning, control and identity" (Hutcheon 1988:13), post-modern culture is dominated by ontological questions (McHale 1989:9-10). It is its aim to not deny, but to question, to subvert, and to undermine these very principles, "but it never offers answers that are anything but provisional and contextually determined (and limited)" (Hutcheon 1988:xi). According to Jean-François Lyotard, modernism is dominated by master- or metanarratives, which provide universal, monolithic answers and truth, with the above principles in the centre. Post-modernism challenges this concept. It breaks down the unquestionable master-narratives into several equal narratives without hierarchy and without the claim to an absolute truth. It also questions the truth of history, since our knowledge of the past is based on its textuality: "it does not deny the existence of the past, it does question whether we can ever know that past other than through its textualized remains" (Hutcheon 1988:20). In opposition to modernism, post-modernism "suggests no search for transcendent timeless meaning, but rather a re-evaluation of and a dialogue with the past in the light of the present" (19). According to Hutcheon, "the presence of the past" is an "important post-modern concept" (4). The engagement with historical events or persons "is always a critical re-working, never a nostalgic "return". Herein lies the governing role of irony in post-modernism" (4). Since post-modernism questions the authority of the established historiography, it seeks new media in order to critically engage with the past. This is done by the inclusion of non-literary texts, such as diaries, anecdotes, newspapers, and of popular genres such as novels and films (an approach which seems familiar to a classicist who - due to the limited existing sources - makes use of every kind of available evidence). This approach bears considerable resemblance to a movement in literary history called "New Historicism", but the works resulting from this approach are subsumed under the heading of what Linda Hutcheon calls "historiographic metafiction" (1988:ix).

McMurtry's Electra may in a sense be regarded as a form of "historiographic meta-theatre", since it displays several features of post-modernist fiction. First, to transpose the ancient myth into the contemporary post-apartheid South Africa and to contextualise it with the work of the TRC shows a clear critical engagement with the past through the medium of actual history. Second, by shifting the focus to female characters and - especially in the case of the chorus - to victims of patriarchal hierarchies, McMurtry illustrates another post-modern characteristic: the shift from the centre to what Hutcheon calls the "ex-centric" (1988:12). While modernism had established clear binary hierarchies, such as male / female, white / non-white, rational / irrational and so on, post-modernism challenges these hierarchies with the stereotypical heterosexual white male in the centre and 
investigates the role of "those who are marginalized by a dominant ideology" (35). Therefore, McMurtry's interpretation becomes "gynocentralising" (65). Third, by giving the chorus such a prominent role in the play, the concept of a single individual subject is subverted by the introduction of multiple narrators, and a "historical plurality replaces atemporal eternal essence" (58). In addition, the overwhelming use of the first person undercuts "the traditional verifying third-person past tense voice of history and realism" (10) and therefore undermines the unquestionable authority of the author. McMurtry also questions the authority of institutions, such as the TRC, the medical profession, the role of the media, and - by workshopping his production traditional theatre practice. Finally, there is the fundamental underlying question of truth. In this context, Hutcheon says that (43)

[...] there are all kinds of orders and systems in our world - and we create them all. That is their justification and their limitation. They do not exist "out there", fixed, given universal, eternal; they are human constructs in history [...] It does, however [...] condition their "truth" value. The local, the limited, the temporary, the provisional are what define postmodern "truths" [...].

\section{South African Electra}

The question of truth is not only central to post-modernism, but it occupies a special place in the history of South Africa. How closely both are linked in the case of the TRC has been elaborated by Eugene Garver:

The Truth and Reconciliation Commission sometimes left multiple narratives and accounts stand without deciding which gets the title of truth [...] [and] rejected the popular assumption that there are only two options to be considered when talking about truth - namely factual, objective information or subjective opinions. Instead, it named four kinds of truth: factual, objective information, personal or narrative truth, social or dialogue truth, and healing and restorative truth (2004:17-18).

Garver points out the ambivalent role of truth(s). On the one side, "[t]ruth is the condition for membership in the community" (18), although truth has been replaced in many "liberal democrac[ies]" by "agreement" and "consensus" (14), because, on the other side, "truth is dangerous and so potentially disruptive" (22; see also 24). But truth has also the ability to transform and to reconstitute existing communities, as can be seen in the case of South Africa: "The South African people learned how to speak and listen in new ways. They built a community out of such discourse" (42). Therefore for Garver "[t]he TRC was a democratic achievement" (42).

Antjie Krog confirms Garver's perception of the relation between truth and the TRC. The question of truth in her book Country of my Skull is very important and very complex. There is the individual truth of each person telling and the truth of listening to their stories. She says: "[...] for the first time these individual truths sound unhindered in the ears of all South Africans. The black people in the audience are seldom upset. They have known the truth for years" (2003:45) and "And every 
listener decodes the story in terms of truth. Telling is therefore never neutral, and the selection and ordering try to determine the interpretation" (85). Then, there is the collective truth for South Africa and its links to justice:

If its [TRC] interest in truth is linked only to amnesty and compensation, then it will have chosen not truth, but justice. If it sees truth as the widest possible compilation of people's perceptions, stories, myths and experiences, it will have chosen to restore memory and foster a new humanity, and perhaps that is justice in its deepest sense (16).

It will take decades [...], generations, and people will assimilate the truths of this country piece by piece (130).

Krog quotes Thabo Mbeki who points out the relation between truth and reconciliation:

The only thing that will heal this country is large doses of Truth ... and the truth is that Apartheid was a form of genocide and a crime against humanity [...] Reconciliation will only be possible if whites say: Apartheid was evil and we were responsible for it (58).

And there is her truth she, Krog, as a writer accounts for in this book:

I am busy with the truth ... my truth. Of course, it's quilted together from hundreds of stories that we've experienced or heard about in the past two years. Seen from my perspective, shaped by my state at the time and now also by the audience I'm telling the story to. In every story there is hearsay, there is a grouping together of things that didn't necessarily happen together, there are assumptions, there are exaggerations to bring home the enormities of situations, there is downplaying to confirm innocence. And all of this together makes up the whole country's truth (170-171).

She concludes that

[t]he TRC succeeded reasonably in establishing factual truth. In determining "what happened". [...] It was less successful in convincing South Africans of the moral truth, of "who was responsible" (290).

Thirdly Susie Linfield convincingly demonstrates that the apartheid regime was based on the bluntly simple lie "that white people are inherently superior to blacks" (2000:2). She continues "[w]hen a society is founded on a lie, the truth assumes particular importance. (It is thus not surprising that truth, or its absence, was an obsession of anti-apartheid writers for decades ...)". Linfield refers to the TRC report which, in post-modern self-awareness of its own limitations, "expressly refuses to anoint itself the arbiter of official, definitive, final truth [...] a truth that will [...] never be fully revealed" (2). By acknowledging the impossibility of an absolute truth, the TRC undermines its own principle "trading truth for justice" (7) - a provisional truth can only lead to a provisional justice. As Linfield discusses in her article, it needs more than the revelation of truth to execute justice. 
This is a particularly interesting aspect for the interpretation of McMurtry's play, since all characters claim (as already in Sophocles' play) to act under the banner of justice (sometimes written with a capital J). In justification of her killing of Agamemnon Clytemnestra states that Justice was her ally and that she helped Justice (McMurtry 2000:15). Electra turns Clytemnestra's argumentation (that she was just in avenging the death of Iphigenia) against her in order to prove that her death will then also be justified (paying for Agamemnon's death) (16). By the same token, both women claim equally to tell the truth (15 and 16). Later, Chrysothemis insists on telling the truth by proclaiming that Orestes has come home (23) - and she is right, despite the fact that Electra proves her wrong, although it is actually Electra who is wrong. Orestes finally speaks the truth, when he reveals the fact that he is still alive and has come back (27-28). And he also claims that he will be doing justice by killing Clytemnestra and Aegisthus, but gives it a strong political undertone:

The oracle was clear. I must obey. And I want to. This is my state, I must restore it, win the throne, [a]nd end the plague on our city. The reign of terror, the corruption. They must pay. I must do Justice here (30; see also 31 and 38)

Here one can see how divergent Electra's and Orestes' perceptions are: while Orestes (as well as Pylades in the prologue) sees the whole enterprise largely as an attempt to save the country, Electra sees it purely as a personal family affair. Orestes, consumed by remorse, will be supported at the end of the play by the members of the chorus who maintain he has done justice (38 and 39). Last but not least, Aegisthus considers the alleged death of Orestes as justice, since he disobeyed and broke the laws of the city (35). And he asks the question what kind of justice will be done by an eternal circle of killing out of revenge - which remains unanswered (36). So there are here several individual truths and conceptions of justice juxtaposed to each other, none of them more true or just than the others.

In conclusion, one might say that McMurtry uses the ancient Electra myth in order to illustrate the situation of South Africa at the time of the production. There are some obvious parallels which invite a link between this particular myth and the TRC. Both deal with the consequences of blood feud, in Electra's case as a family affair, for the TRC within a political framework. How can one cope with the consequences of the murder of a loved one or any other personal injury? By vengeance? Forgiveness? Truth? Whose truth? Justice? Whose justice? McMurtry presents a society which is still struggling with the past and is in the process of re-defining and re-establishing itself. According to Simpson "[i]t is a society which has suffered the chronic trauma of apartheid and the effects of its acute events" (1995:188). The same scholar expressed with bitter resignation a harsh verdict about the situation of "survivors of apartheid" in the New South Africa. He said that

[t]hose who dreamed of freedom and recognition for their contribution to attaining it have been trampled, and express no hope for the future: a situation far worse than their state under apartheid, for no one will liberate them from the Liberation that failed to set them free (Simpson 1995:210). 
McMurtry paints a post-modern condition in which the old order has been put into question, but has not yet been replaced by a new one. The clear-cut binaries of the past are disturbed; there is no longer a clear definition of who is masculine or feminine, who is the villain or the victim. The hearings of the TRC have shown that it is impossible automatically to associate white with bad and black with good, since many black perpetrators disclosed the crimes they committed against white and black people. By returning to the ancient sources in his adaptation of the story of Electra, McMurtry indicates the scope of the task South Africa still has ahead of it: to consolidate itself as a multi-racial democracy.

\section{BIBLIOGRAPHY:}

Fleishman, M 1990. Workshop Theatre as oppositional form. South African Theatre Journal 4,1: 88-118.

Foster, H (ed.) 1990. Postmodern Culture. London \& Concord, Massachusetts: Pluto Press (first edition: 1983).

Garver, E 2004. For the Sake of Argument. Practical Reasoning, Character and the Ethics of Belief. Chicago \& London: The University of Chicago Press.

Herbstein, D 2004. White Lies. Canon Collins and the secret war against Apartheid. Cape Town: HSRC Press \& Oxford: James Currey Publishers.

Hodgkinson, P E \& Stewart, M 1991. Coping with Catastrophe. A Handbook of Disaster Management. London \& New York: Routledge.

Hutcheon, L 1988. A Poetics of Postmodernism. History, Theory, Fiction. London \& New York: Routledge.

Krog, A 2003. Country of my Skull. Johannesburg: Random House (first published in 1998).

Linfield, S 2000. Trading Truth for Justice? Reflections on South Africa's Truth and Reconciliation Commission (http://www.bostonreview.net/BR25.3/linfield.html).

McHale, B 1989. Postmodernist Fiction. London \& New York: Routledge (first edition: 1987).

McMurtry, M 2000. Electra. Production book (unpublished).

Peterson, K C, Prout, M F \& Schwarz, R A 1991. Post-Traumatic Stress Disorder. A Clinician's Guide. New York \& London: Plenum Press.

Schlebusch, L 2000. Mind Shift. Stress Management and your Health. Pietermaritzburg: University of Natal Press.

Scotti, J R et al. 1995. The Psychological Impact of Accidental Injury. In Freedy, J R \& Hobfoll, S E (eds.), Traumatic Stress. From Theory to Practice, 181-212. New York \& London: Plenum Press.

Simpson, M A 1995. What Went Wrong? Diagnostic and Ethical Problems in Dealing with the Effects of Torture and Repression in South Africa. In Kleber, R J, Figley, C R \& Gersons, B P R (eds.), Beyond Trauma. Cultural and Societal Dynamics, 187-212. New York \& London: Plenum Press. 
Vesti, P \& Kastrup, M 1995. Refugee Status, Torture and Adjustment. In Freedy, J R \& Hobfoll, S E (eds.), Traumatic Stress. From Theory to Practice, 213-235. New York and London: Plenum Press.

Interview with Professor Mervyn McMurtry on 1 July 2004 in Durban. 